\title{
DISTANCE LEARNING AND NEW FORMS OF DISCIPLINE DURING THE PANDEMIC
}

Izvorni znanstveni rad Primljeno:29. 1. 2021 Prihvaćeno: 10. 3. 2021. DOI: $10.15176 /$ vol58no105 UDK $342.744: 37.018 .43$ 616-036.22COVID-19

\section{BARBARA TURK NISKAČ \\ ZRC SAZU, Institute of Slovenian Ethnology, Ljubljana}

\begin{abstract}
In the $19^{\text {th }}$ century, compulsory education was introduced as a means of discipline within a new work ethic formed in the moral discourse of productivity and the state's preoccupation with increasing profits. During the COVID-19 pandemic, the compulsory schooling of children in Slovenia moved into the homes with the help of distance learning and technological solutions made possible by the digital revolution. As managing the shift to distance learning was left largely up to schools with little support from state structures and since much of the responsibility fell on parents, especially those with younger children, the Minister of Education publicly proclaimed students the corona winners of knowledge, winners of our and future times. Distance learning, however, cannot be considered in isolation as the pandemic changed how we organise all of our daily life. Each in their own way, families were confronted with coordinating their children's distance learning, family obligations, work, and leisure. By analysing the reorganization of family daily life, the issues of protecting the privacy of students and their families, and the functioning of online market mechanisms, the paper presents distance learning as a new form of disciplining children between entrepreneurial work ethics, digitalisation, and biopolitics.
\end{abstract}

Keywords: distance learning, surveillance capitalism, human capital, COVID-19 pandemic

\section{INTRODUCTION}

The verse razumeti nazaj, živeti naprej (to understand backward, to live forward) from the poem Mala bivanjska (A Little Existential Poem) by Ana Svetel will serve as a starting point in my discussion of the disruption in the Slovenian school system caused by the COVID-19 pandemic.' While life can only be lived in the present, in the here and now, it is

${ }^{1}$ This article was written within the postdoctoral project Z6-1881 and the research programme P6-0088 funded by the Slovene Research Agency. I would like to thank the anonymous reviewers for their observations and comments, and for drawing my attention to Michael W. Apple's and Henry A. Giroux's work. 
essentially derived from the past. Therefore, if we are to understand the present, we first need to understand the past. However, if we want to move forward, we must not look back, we must look onward, to the future. This is the only way we can move forward without getting stuck in the present or, worse still, in the past.

As humans, we like to concern ourselves with predicting future events, but the future remains generally unknown and uncontrollable, revealing the limitations of the human mind. This becomes particularly clear when we are confronted with the unknown or unprecedented, to borrow the term from Shoshana Zuboff. The human mind is inherently restricted to interpreting the unprecedented through past experiences and familiar categories "thereby rendering invisible precisely that which is unprecedented" (Zuboff 2019: 12). Thus, limited by our own past experiences, we fail to grasp the unprecedented - it inevitably remains unrecognizable.

Following Shoshana Zuboff's (2019) analysis of the unprecedented form of power called surveillance capitalism and the desire of corporations to predict and control our behaviour by increasing the surveillance of our most quotidian activities, I situate this article in the realm of imagining the possibilities of new forms of discipline in the educational sector after the disruption caused by the pandemic. My intention is not to predict the future, but to build on the knowledge of the past and on the observations of the present thus stimulating discussion about possible futures.

In spite of the much broader function fulfilled by schools in the local context - such as socialisation and emergence of children's and youth cultures - this article focuses on the function of schools in preparing children for the future labour market and aims to present how new forms of discipline can be understood in the case of distance learning. Such a narrow understanding of the purpose of schooling is embedded in human capital theory, which categorizes children "as investment goods providing an income for the country or as future human capital" (Millei 2020: 930) and thus aims to restructure schools in line with market requirements. This view is most prominently promoted by the OECD and the World Bank, which perceive "the role of human capital as a major opportunity in the context of globalization, innovation, knowledge and technologies" (Millei 2020: 931; see also Griffiths et al. 2013). These concepts all play a significant role in changing schooling during the pandemic, although neoliberalism has long shaped the domain of children's lives with its objective "that children should become competitive in the market place" (Hart and Boyden 2019: 80). Building on human capital theory - which sees education and training as the most important investments in human capital (Becker 1993), neoliberal ideology (Berardi 2009; Holmer Nadisan 2010; Apple 2013; Bröckling 2016; Ortner 2016; Harvey 2017; Spyrou et al. 2019; Giroux 2021), and surveillance capitalism in the age of digitalisation (Zuboff 2019) - I analyse the experiences of students and their parents with distance learning in the first wave of the pandemic and scrutinize media texts presenting decision making with regard to schooling during the pandemic to suggest that distance learning is a new form of discipline amidst the changing economic system in the digital age. 


\section{THE EMPIRICAL STUDY}

\section{METHODOLOGY}

This article draws on studies dealing with the conceptualizations of work in relation to play and leisure in childhood in Slovenia (both in the context of the family and in institutionalized education) across generations as well as studies dealing with the transformation that these conceptualizations underwent relative to the political, social, and economic circumstances (see Turk Niskač 2021a; 2021b). For my doctoral thesis, I conducted an ethnographic study in two kindergartens in the years 2010-2013 using participant observation and video recordings, semi-structured interviews with parents, grandparents and teachers, participatory photography, and photo elicitation interviews with parents, teachers, and children aged three years and older. In the years 2019-2020, I continued this study as a postdoctoral research project investigating the changing conceptualizations of work, leisure, and play in the childhoods of primary school children and their families using semi-structured interviews, participatory photography, and photo elicitation interviews. ${ }^{2}$ In total, 24 parents (20 mothers and 4 fathers), 5 grandparents ( 3 grandmothers, 2 grandfathers), and 26 children aged six to fourteen (12 girls and 14 boys) from both urban and rural areas took part in my postdoctoral study, which ran between October 2019 and August 2020.

Due to the lockdown interruption, I conducted an online survey, which was open between 6 and 31 April 2020. ${ }^{3}$ The online survey included 359 parents from all over Slovenia with at least one child in primary school. On average, the respondents lived in households of 3.2 persons and had 2.2 children. The largest proportion of parents held a university degree (44\%) and were permanently employed (65\%). Other respondents were in various types of employment, ranging from cultural workers, self-employed workers, temporary workers, to farmers and the unemployed. During the spring lockdown, the vast majority of parents worked from home (45\%). The proportion of parents on hold (16\%) or working outside the home (16\%) were the same. However, a number of parents also combined working from home with working at the workplace (see also Turk Niskač 2020a). The survey included both open- and closed-ended questions about the children's schooling, leisure, and work activities at home, both before the lockdown and during the spring lockdown. Closed-ended questions were aimed at ascertaining how parents evaluated various children's activities (extracurricular activities, play, and outdoor recreation as well as chores, schooling, and digital platforms). Open-ended questions, for example, asked about the types of extracurricular activities a particular child attended before the

\footnotetext{
${ }^{2}$ Both studies obtained ethical clearance from the Ethics Commission of the Faculty of Arts, Ljubljana. All data has been anonymised.

3 The survey was anonymous and in line with the General Data Protection Regulation (GDPR). As a mother of three elementary school children myself, I distributed the survey through my many acquaintances via email and Facebook and asked them to forward it.
} 
lockdown and which of these he or she attended online during lockdown; some inquired as to the types of household chores the child participated in before the lockdown, whether the distribution of household chores among the family members changed during the lockdown, about the children's role in this, etc. Most of the data for this article is derived from the analysis of the open-ended questions about the positive and negative effects of the lockdown on the way children spend their free time and on family life dynamics, and photo elicitation interviews with children.

In order to gain a better understanding of governmentality in times of crisis, I also analysed media texts and official governmental websites presenting decision-making about schooling during the pandemic in 2020-2021.

\section{THE STRUGGLES OF DAILY FAMILY LIFE DURING THE LOCKDOWN}

When Slovenia was hit by COVID-19 in the spring of 2020, the state went into complete lockdown, which included closing all schools. Virtually overnight, schools went fully online without detailed instructions on how to implement distance learning provided by state structures such as the Ministry of Education. While some teachers sent instructions for school work to the pupils only in PDF format by e-mail or in some cases even by post, others used the e-classrooms of ARNES (The Academic and Research Network of Slovenia), a public institution providing networking services for educational organizations, and still others used ZOOM, MS Teams, and other educational technologies, for example Padlet, as well as communication channels such as YouTube, Viber, Facebook and WhatsApp.

The measures accompanying the pandemic during the spring lockdown relegated key social activities, such as the schooling of children, work obligations, family obligations, and leisure time to the sphere of the immediate family and home. The family household thus became the place of socialising, education, as well as work. Meanwhile, the responsibility of successfully implementing distance learning in practice fell on individuals - teachers, pupils, and their parents, who simply did not have equal conditions for schooling and working at home, which was also attested by the semi-structured interviews with children and their parents, and the results of the online survey.

The study demonstrated that for numerous families, the spring lockdown slowed the pace of life and provided an opportunity to experience an existence without rushing or stress; children had more time for family nature outings, creativity, participating in household chores, and unstructured play. On the other hand, parents working from home were also faced with the stress of reorganising their time, which was now spread between work, family and school obligations at home. As one of the respondents wrote: "Since both my husband and I work from home, we have difficulties because we cannot engage with children while working". Another mother similarly responded: "We both work and find it difficult to coordinate the younger child's distance learning and work. The children spend 
more time with us, and we have virtually no time to ourselves. One starts work early in the morning, the other finishes work late in the evening".

Parents who worked outside the house even during isolation highlighted the fact that children were left to themselves, that the parents had less "time to follow what they were doing", and to engage with the children and their schoolwork. The impossible act of balancing work and school obligations at home was followed by a chronic lack of free time, and "time for oneself", as attested by the following statement: "Nervous parents, because you can't take care of your job, and school, and cooking, and ... everything. Difficult organisation. Unrest".

Mothers and single-parent families particularly suffered the brunt of the burden, as evidenced by the following statement: "It's more difficult for parents (particularly mothers/ teachers etc.) to have some time to ourselves - to do nothing, our job, for physical activity, creativity". Distance learning was a frequent source of disputes, tension, stress, and quarrelling between family members. Parents specified that reconciling work and schooling at home was strenuous; consequently they "only assumed the roles of teachers sloppily". Financially better-off parents can of course always afford to pay for home childcare and education assistance. One respondent wrote: "Work from home while distance schooling three children takes too much time, which is why I will arrange for paid child care, which consequently means lower family income." In the case of distance learning, transferring schooling to the private sphere of the home and reassigning responsibility to the private domain of the family therefore further amplifies the processes of widening the social inequality gap between children relative to the economic, social, and cultural capital of their families, the importance of which was already outlined by Pierre Bourdieu (1997).

Most notably, parents noticed that their children missed company, there was a "lack of motivation to fulfil school obligations", "diminished interest in schoolwork", "less learning". They emphasised that children only "do the essential tasks; they don't solidify their knowledge". The discussions I had with children as part of my research also attest that during distance learning, children primarily missed their school friends, teachers and school clubs, and that they took part in domestic chores more (e.g. cooking and baking). As far as positive aspects are concerned, some highlighted their ability to arrange their own schoolwork schedules; for example, a $1^{\text {st }}$ grade primary school student explained she liked the fact that she could arrange her time by herself and had more time for play: "[I missed] the teacher a little, and girlfriends a little, other than that I was happy to be home because I didn't have to go to school, I could go out and play a bit and such. Yes, and I could arrange it myself, while in school she [a teacher] arranges what you have to do." On the other hand, children often missed out on explanations of new material: "It wasn't good, 'cause - you know - it wasn't explained very well; she just wrote it down but she didn't... I don't know - if there was a new topic, it was really hard for me to understand, it would be easier for me to understand if I was in school" ( $3^{\text {rd }}$ grade student). 


\section{TECHNO-OPTIMISM: "CORONA WINNERS OF KNOWLEDGE"}

The government and public authorities in Slovenia (e.g. the Ministry of Education and Sports and the National Education Institute) focused primarily on providing technical equipment to schools and families. However, even having their own computer for independent work and a fast Internet connection could not help children with low intrinsic motivation and poor self-regulation. This is demonstrated by the experience of a $6^{\text {th }}$ grade primary school student: "It was totally annoying to me, I really didn't feel like working, and I was like 'no, not again' and then I could hardly wait for the holidays; I mean art and shop class were fine, when you make things on your own, I'm good at that, but I didn't feel like doing the other stuff. I was fed up, so I just did everything halfway and stuff".

Even though expert education workers warned during the spring lockdown that distance learning was widening the gap between children from the most vulnerable groups (children with special needs, children of immigrants, children from socially disadvantaged families, etc.) and others, the Minister of Education along with the media summing up her words, insisted that distance learning was a success and labelled students 'the greatest winners', ${ }^{4}$ 'the winners of knowledge of our time and of times to come', 5 in short 'the corona winners of knowledge'. Any potential future policy would greatly benefit from knowing to what extent students were able to meet their educational goals in the course of distance schooling, yet no such study was conducted in Slovenia. Other studies conducted at the time, however, suggest that on average students were learning less in these circumstances and that students from the most disadvantaged families were disproportionately affected both in their cognitive and non-cognitive skills acquisition (DiPietro et. al. 2020; Engzell et al. 2021). And yet, the Slovenian state authorities refuse to give up their "success story of the corona winners of knowledge" to this day. When we think in terms of winners, we could assume that a competition has taken place. Why would anyone see a time when the pandemic brought all social life and, to a large extent, economic life to a standstill as a competition? Who was competing against whom? What was the competition about? And if we have winners, who are the losers?

The discourse of winners once again reveals neoliberal discourse, in which "young people are obliged to compete in a marketized economy and society of winners and losers" (Hart and Boyden 2019: 84). Considering students' personal characteristics, it seems that the winners of distance learning were those students who had a strong capacity for memorisation, concentration, motivation, fast reception and processing, and information integration. We see the conception of efficiency transforming from production-based to computer information-processing-based (paraphrasing Lee 2013: 87). With the advent

\footnotetext{
${ }^{4}$ https://www.rtvslo.si/slovenija/ucenci-zmagovalci-znanja-se-vracajo-v-solske-klopi-a-ne-vsi/524115 (accessed 15 December 2020).

5 https://www.gov.si/novice/2020-05-18-pismo-ministrice-prof-dr-simone-kustec-ob-nadaljevanju-solskega-leta/ (accessed 15 December 2020).

${ }^{6}$ https://casoris.si/ministrica-simona-o-soli-in-pocitnicah/ (accessed 15 December 2020).
} 
of TikTok and YouTube, influencers in the field of education prove that innovation and self-promotion are to be seen as virtues, signalling to individuals that as influencers they can even make money on social networks by marketing brands, while at the same time the boundaries between leisure and work are being blurred and their privacy is being eroded (see Turk Niskač 2020b; see also Biti 2020). Other virtues that turned out to be important were emotional resilience and mental stability, the capacity to be effective in uncertain and stressful situations, which we can expect more of in future. Needless to say, these virtues are all agglomerated within a human capital discourse (see Lee 2013: 83) presented in the introduction to this article.

\section{CLOSING SCHOOLS IN THE NAME OF PROVIDING EQUAL OPPORTUNITIES FOR ALL STUDENTS}

In the autumn of 2020, with the second wave of the pandemic, Slovenia was one of the few European Union countries to close schools, including special education schools, completely and early on. Although the Ministry of Education and the National Education Institute prepared four main models with different sub-models of the educational process depending on the epidemiological situation, the majority of these were never attempted in practice; instead the most restrictive model of fully remote learning was selected for all students in the second and third month of the school year, which led to one of the longest school closures in Europe.? Various experts and the media in Slovenia continued

\footnotetext{
${ }^{7}$ Pupils from the $6^{\text {th }}$ grade of primary schools and all secondary schools went into distance learning from 19 October 2020. After an extended autumn break, from 9 November 2020, pupils in grades 1 to 5 and special education schools also followed with distance learning. Although the majority of experts in the fields of psychology, child psychiatry and education, as well as parents, seemed to be in favour of opening schools at least for younger students, a group of parents concerned about their children's and other family members' health had created a Facebook group opposing opening schools too early (https://www.facebook.com/ Iniciativa-proti-prehitremu-odpiranju-\%C5\%A1ol-104695404800918, accessed 28 January 2021). On the other hand, school closure was particularly damaging to children in special education schools, which also provide them with various therapies. A group of parents of children with special needs filed an initiative with the Constitutional Court, which issued a decision that the deadline for re-opening special education schools was 4 January 2021 (https://www.rtvslo.si/slovenija/ena-od-pobudnic-ustavne-presoje-veselim-se-odprtjasol-ceprav-ne-bo-enostavno/546696, accessed 28 January 2021). On 25 January 2021, schools reopened for grades 1 to 3 in regions with an improving epidemiological situation, but all other students continued with distance learning. At that time, some primary and secondary school students formed a movement called "We Demand School" and addressed an open letter to the Minister of Education demanding the opening of schools and announcing a strike if the Minister did not listen to them (https://www.delo.si/novice/slovenija/ mladi-napovedujejo-stavko-ce-jih-ministrica-ne-bo-uslisala/, accessed 28 January 2021). However, already on the third day after the reopening of some schools for grades 1 to 3 , it was announced that in two regions with a worsening epidemiological situation, classes would resume through distance learning, with the innovation that classes would be held in school only for the children of "essential workers" (https://www.rtvslo. si/slovenija/po-nekaj-dneh-konec-pouka-v-solah-v-zasavski-in-obalno-kraski-regiji/550510?fbclid=IwA R0OJOeJ5K7BW21YKsltdA_GXEbgp42bz2ZdCtpW5GaPX_dpIAd_KCzlsRk, accessed 28 January 2021). Some parents and students in these two regions decided to protest against school closure, and eventually these schools remained opened (https://4d.rtvslo.si/arhiv/tarca/174751480, accessed 15 March 2021). On 15 February, primary school students from grades six to nine and the last grade of secondary schools finally
} 
to warn that distance learning increases inequalities between children (e.g. some children in remote rural areas do not even have access to the internet) ${ }^{8}$ which is particularly worrying for children with special educational needs. ${ }^{9}$ However, the Minister publicly defended the decision to close all schools including special education schools as measures taken precisely in the name of providing equal opportunities for all without giving any credible argument to this effect beyond the one that all children are granted online schooling and therefore continue their schooling under equal terms ${ }^{10}$ (see also Logaj 2020: 5). From the beginning of school closures, the Minister specifically defined students as more digitally competent than their teachers and parents, as "the ones who will lead the way".11 This is even more surprising given numerous international studies showing that not all children are the "well connected, digitally savvy, 'digital natives' that the rhetoric around young people and technology would have us believe" (Williamson et al. 2020); that "technology cannot fix social inequality" (ibid.; see also Bond 2013; 2014; Lahikainen et. al. 2017; see also Danby et. al. 2018), and that the pandemic "has exposed and often amplified the existing inequalities in education systems across the world" (Sahlberg 2021; see also Jæger and Blaabæk 2020). In fact, already before the pandemic, neoliberalism globally subjected every sector of society including education "to the logics of commodification, marketization, competition, and cost-benefit analysis" (Apple 2013: 6), which supposedly lead to better schools and greater equality, whereas, in fact, they did not actually alter the relations of inequality that generally characterise schooling (ibid.).

\section{DIGITAL TRANSFORMATIONS AND EDUCATION}

Apart from seemingly supporting the provision of providing computers and technological support for distance learning, the Slovene Ministry of Education seemed to be concerned not so much with children's daily experiences in the present, but rather with the Ministry's

\footnotetext{
also returned to schools and it was decided that all schools would remain open regardless of the regional epidemiological situation. On 8 March, all other secondary-school students returned to school in line with model C, their classes alternating weekly between distance learning and classroom instruction (https://www. rtvslo.si/slovenija/v-sole-dijaki-vseh-letnikov-zacenja-se-prednostno-cepljenje-solnikov/572029, accessed 17 March 2021).

${ }^{8}$ https://4d.rtvslo.si/arhiv/tarca/174731947 (accessed 14 March 2021).

${ }^{9} \mathrm{https}$ //necenzurirano.si/clanek/aktualno/kako-je-simona-kustec-pustila-na-cedilu-najranljivejse-otroke-857318 (accessed 15 March 2021).

10 https://www.rtvslo.si/4d/arhiv/174731947?s=tv (accessed 15 December 2020).

${ }^{11}$ In an open letter to students in May 2020, the Minister of Education wrote: "You are proving it to your teachers, to us parents - proving it to everyone, to all of society. You are opening doors to new worlds for us "old folks", doors to your tomorrow, which you know and master better than most of us. At this very moment, you helped us understand how and why computers, smartphones, and the World Wide Web really matter. Until recently, we were convinced that you only knew how to use them for games and stupidities. What a mistake!" (https://www.gov.si/novice/2020-05-18-pismo-ministrice-prof-dr-simone-kustec-ob-nadaljevanjusolskega-leta/, accessed 15 December 2020).
} 
visions of the future, which is attested in the language focusing on new opportunities and innovation in the age of digitalisation:

In the event that the epidemiological picture deteriorates, the Ministry of Education, Science and Culture, together with public institutions, will create material working conditions and thus indirectly establish a comprehensive supportive innovative learning environment that enables high-quality distance teaching. Such an approach to digitising education thus offers new opportunities in the field of learning and innovative teaching approaches. (Logaj 2020: 92)

Furthermore, the digital transformation of the education system was also announced as a priority of the Slovenian Presidency of the Council of the European Union in 2021,12 with green and digital transformations among the European Commission's priority tasks for the coming years..$^{13}$ Although current distance learning has been repeatedly touted as an opportunity for the future vision of knowledge (see also Logaj 2020: 6), interestingly enough, this future vision has never been publicly announced or discussed. At best, in an interview published on 29 November 2020, the Minister announced that in the next school year, we can expect digitised teacher work plans and curricula for all subjects and all grades of primary and secondary schools: "In this new electronic form, we are adding all digital teaching materials and tools, including textbooks, workbooks, and various computer applications. With this we are finally building a modern, digitally supported education system."14

While it would certainly make sense to include digital knowhow, a command of digital skills, as well as data protection issues and an understanding of the Internet and marketing mechanisms behind it in the school curriculum, the vision of future education does not seem to focus on such knowledge but on the mere capacity to use online tools. Up until the pandemic, the prevailing critical opinion was that digital technology can represent added value, but can by no means entirely replace real-life teaching in a physical classroom. In this respect, the pandemic turned out to be a great opportunity to speed up these processes, to modernise the school system to make it more innovative and digitised. However, I suggest that modernise here essentially stands for adapting to the new principles of the workings of the capitalist system, where the need for a workforce is diminishing, while, in order to function and increase profits, the changing capitalist system now needs people as raw materials in the digitalized world (see Zuboff 2019).

12 https://www.gov.si/novice/2020-11-30-eu-ministri-za-izobrazevanje-mladino-in-raziskave-izobrazevanje-in-mladi-so-se-odzvali-hitro-in-ucinkovito-sedaj-je-cas-za-konkreten-premik-naprej/?fbclid=IwAROvaWyCHq9WAO9-aHaVw_oi2unwcnUDyaZOaYhEYiBXT1EMCAmgM5KHvbo (accessed 15 December 2020).

${ }^{13}$ https://ec.europa.eu/info/strategy/priorities-2019-2024/europe-fit-digital-age_en (accessed 15 March 2021).

${ }^{14}$ https://novice.svet24.si/clanek/novice/slovenija/5fc3c651480b9/intervju-ministrica-simona-kusteco-vrnitvi-solarjev-v-solske-klopi-in-zunanjih-pritiskih?fbclid=IwAR2-oAcA9iYEimJoi-vBLzrMBayeOpdkCgg4ZKAjPhDFyPrNvlsHbOWrtWA (accessed 15 December 2020). 
Moreover, the narrow understanding of children as human capital, which appears to be at the heart of the Slovene Ministry's visions of the future development of the education sector "neglects the effects of market forces and the economic, social and political power hierarchies that shape children's development and opportunities in life as well as class, racial, and gender divides" (Millei 2020: 930). This is also illustrated by the gap between the government public authorities' visions and teachers', pupils' and their families' everyday experiences. Zsuzsa Millei points out that looking at children through the prism of economic theory alone denies them "their humanity, certain rights to life, freedom and the pursuit of happiness" (ibid.). It is the aim of neoliberalism that children should become competitive in the market place, which also profoundly shapes the domains of children's lives. In particular, concern for future viability and success is a vital force in children's everyday lives (Hart and Boyden 2019: 80). However, what matters to children more than adults, is the present with the here and now, rather than abstract visions and outcome calculations for the future.

Despite families' daily struggles and calls by experts in the fields of psychology, child psychiatry, and pedagogy to reopen schools, the Minister of Education refused to consider it, constantly reiterating the promise that school reopening was a priority as soon as the epidemiological situation allowed it and as soon as "the experts gave the green light". However, experts such as the head of the Pediatric Neurology Department at University Children's Hospital in Ljubljana, a government expert group and a representative of the National Institute of Public Health all recommended that the Minister should reopen special educational needs schools regardless of the epidemiologic situation as early as December 2020, at a time when the Minister was still publicly defending her position by saying that she was "waiting for the green light from the experts". ${ }^{15}$ Special educational needs schools were reopened only after a group of parents filed an initiative with the Constitutional Court, and the Court decided in their favour. However, in March 2021, the Minister successfully passed an interpellation brought against her by the opposition for the longest school closure in Europe. As her defence, the Minister expressed her conviction that there were no grounds for passing the interpellation given the successful work of the Ministry of Education during the pandemic, stating, "We know what we're doing, we know why we're doing it, and most importantly, we know who we're doing it for". 16

On the other hand, visions of the future can also be emancipatory. One such vision inspired by the Māori lore envisages the pandemic as the opportunity "to create a reschooled society", which places "humans at the center of schooling; to revise schools as core social centers so that there is integration of learning, employment, welfare and health services for the benefit of all" (Brown 2020). Furthermore, Henry A. Giroux (2021) argues that in times of uncertainty, fragmentation, and despair - which mark the pandemic crisis

15 https://necenzurirano.si/clanek/aktualno/kako-je-simona-kustec-pustila-na-cedilu-najranljivejse-otroke-857318 (accessed 15 March 2021).

${ }^{16}$ https://www.rtvslo.si/slovenija/simona-kustec-ostaja-ministrica/572968 (accessed 14 March 2021). 
- critical pedagogy is needed more than ever to establish a symbolic relationship with the world, highlighting its tools of resistance in the struggle over power, knowledge, agency, and social relations (see also Giroux 2020). Given many alternative educational models that have long been discussed and implemented (Woods 2009; Freire 2013), with some schools opting for outdoor desks and outdoor learning during the pandemic, ${ }^{17}$ and the fact that Slovenian state authorities prepared four possible models with several sub-models for the 2020-2021 school year (Logaj 2020) only to opt for one of the longest school closures and distance learning, it is all the more imperative to understand the governmentality driving the decision-makers.

\section{BACK TO FOUCAULT, BACK TO THE FUTURE}

\section{COMPULSORY EDUCATION: MODES OF DISCIPLINARY FORMATION}

In Discipline and Punish (1995), Foucault explained the mechanisms of the historical production of human individuality and the specific historical form of sociality in connection with the birth of the capitalist social system, which placed work at the centre of social organization - not just any work, but productivity-oriented work. The processes were lengthy because in the Middle Ages, work was not the domain of all members of society; society was divided into those who pray, those who fight, those who work, and beggars, bohemians and vagabonds. With a social organization that put work at the centre of its activities, we can trace a turning point where idleness and laziness became a source of crime and evil - yet people had to be taught a new work ethic. In France, for example, since the $16^{\text {th }}$ century (before the introduction of compulsory education), great confinements of vagabonds and paupers were enacted to reduce the risk of plague infection. At the same time these 'useless' individuals, many of whom were children and adolescents, were being disciplined to perform productive work and use their time effectively (Foucault 1995; Pezelj 2016).

In Slovenia, compulsory schooling was introduced during Maria Theresa's reign, the school's role at the time was to create virtuous, hard-working, orderly, compliant, obedient, well-behaved individuals and thus bolster the government's authority and increase production and profits. However, with late industrialisation and predominant agrarian family economy, work was often prioritized over school because the survival of the family depended on physical work performed by all members of the household, including children. It was not until accelerated modernisation and industrialisation in the wake of World War II that socialist Yugoslavia succeeded in really strengthening school education, and thus

17 https://abc7.com/outdoor-learning-school-classroom-covid-19-pandemic/6360069/; https://www. theguardian.com/uk-news/2020/may/10/scotland-eyes-outdoor-learning-as-model-for-reopening-ofschools (accessed 16 March 2021). 
meeting the state's need for qualified workers, technical professions, and an educated workforce (Turk Niskač 2021a). The question which therefore follows is: how is school to fulfil the needs of the state or the market in these modern times, which are characterized by market deregulation, reduced job stability, ever greater uncertainty, production automation, and digitalisation?

\section{THE CHANGING ECONOMIC SYSTEM AND ITS IMPLICATIONS FOR EVERYDAY LIFE}

Ever since the 1980s, neoliberalism as a mode of governmentality has been striving worldwide to transfer the state's responsibility to private institutions and individuals (Holmer Nadesan 2010: 100) with implications for the field of education (Apple 1993: 228; see also Apple 2019). Viewed in this context, and in the context of the digital revolution of the recent years, the pandemic has not really introduced much in the way of new processes, but rather speeded up those that had already been underway. Two key processes which relate to changes that work plays in social organization include the relationship between work and leisure and between work and home and/or family life.

The industrial revolution separated work and family life and relegated the family to the private sphere (Federici 2012), whereas the digital revolution is breaking down the divisions between professional and family life, between work and leisure, and between the public and private spheres. These divisions were greatly exacerbated by the pandemic, when governments took measures to protect the health of the population, which included working from home when possible. While some jobs could indeed be done from home, during the pandemic this was clearly a privilege not all shared (e.g. medical personnel, low-skilled workers, merchants, delivery jobs, etc.). As the experiences of the interviewees featured in this article show, the shift to working from home was often accompanied by the struggle of reorganizing work in line with distance learning, childcare, and other family obligations.

Nonetheless, in December 2020, the Slovene Ministry of Labour, Family, Social Affairs and Equal Opportunities released a commercial titled "What it's like to work from home when you have a family", with the aim of encouraging more people to choose to work from home during the pandemic. On the one hand, the commercial highlighted to employers the benefits of making the work process more flexible and reducing operating costs. On the other hand, it emphasized that working from home had a general positive impact on the balance between work and family life; employees no longer waste time commuting, reducing the burden on the environment and infrastructure. The most interesting part of the commercial was its idealized account of a day in the life of a family working from home: family members do not have to rush in the morning, they can eat their breakfast in peace, work and study in comfortable clothes, pets can accompany children during 
distance learning, and the family can eat lunch together and exercise outside. Finally, parents who work from home do not pollute the environment with traffic, protecting their own health and that of their loved ones. The commercial clearly pointed to political visions that go beyond protecting public health, namely social reorganization in the midst of climate change and labour market restructuring. However, it failed to take into account the everyday reality of families facing widening social inequalities and daily struggles during the pandemic, and was removed from the Ministry's social media shortly after its release due to public outrage, after which the Minister also issued a public apology.

\section{THE ENTREPRENEURIAL INDIVIDUAL}

Throughout the $20^{\text {th }}$ century we can observe the shift "from a Fordist regime of accumulation, resting on industrial production, to a post-Fordist one, dominated by finance" (Fraser 2017: 69). With the financialisation of recent decades, labour no longer occupies a central place in capital accumulation, and actual products are being replaced by financial products in investment and capital accumulation (Holmer Nadesan 2010; Fraser 2017; Harvey 2017). Marked by the subordination of all forms of social organizations to the imperative of financial markets, neoliberalism represents "a political-economic-cultural domination of a capitalist oligarchy and the coercion of an economy driven by the unrestricted accumulation of capital" (Brie 2017: 44) relying on "privatisation, austerity policy, [and] regulation in the interest of the central oligarchies of financial-market capitalism", organising society according to the "market model" (Brie 2017: 45). The financialisation of everyday life has also created new conditions of childhood with social relations and social practices increasingly entangled in capitalist accumulation (Spyrou et al. 2019: 15, 16). Most obviously, the market model reshapes childhoods through a process of privatization in various meanings of the term, including the withdrawal of the state as the provider of welfare (Hart and Boyden 2019: 78; see also Kovačič and Dolan 2017).

Furthermore, under the influence of financialisation, the work ethic that was shaped in the moral discourse of productivity and increasing profit has already been replaced by an entrepreneurial work ethic, which injects all facets of human relationships with entrepreneurial principles and market mentality or market efficiency (Gorz 1999; Berardi 2009; Narotzky and Besnier 2014).

According to Foucault, neoliberalism transforms homo oeconomicus, who is no longer a partner in the exchange, but an entrepreneur of himself, being for himself his own capital, his own producer, and source of income (2008: 226). The entrepreneurial individual must be a good manager of her or his life, innovative, flexible, constantly improving and adapting to market pressures in order to ensure competitiveness and innovation in the labour market (Holmer Nadesan 2010; Vodopivec 2012; Berardi 2009). This creates competition in which only the best succeed, but which is a myth, because it is clear that even such 
great effort and investment do not exclude the possibility of failure (Bröckling 2016). The production of such a neoliberal subject, "the freely choosing individual" is the "hegemonic form of governmentality in the neoliberal word" (Ortner 2016: 55). In addition, the neoliberal subject is also responsible for risk management, because in the neoliberal discourse risk management is transferred from state and public institutions to individual and private institutions. This is intended to foster individual responsibility, initiative, and innovation and is seen as crucial to competitive trade (Holmer Nadesan 2010; Bröckling 2016).

\section{THE CHANGING ROLE OF THE STATE: SHIFTING RESPONSIBILITY}

Even though the state's responsibility to guarantee the conditions for the execution of compulsory primary education is stipulated in the Slovenian constitution (Article 57), ${ }^{18}$ the pandemic demonstrated a growing trend of the state shirking this responsibility and transferring it to the individual while opening the door to corporate/private interests. In addition to widely opening their doors to technological corporations, schools have again charged families with significant responsibilities previously divided between the family and schools, from organizing time devoted to learning, play, and extracurricular activities, ${ }^{19}$ to providing nutritious daily meals, to promoting health and recreation, as one principal's letter to parents clearly illustrates:

It is very important that you help a child divide time at home between school and free time, recreation and socializing with family members. [...] It is important that you talk to your children a lot, listen to their distress, and try to help them with clarifications and right answers. [...] You should dedicate at least one hour of free time per day for family physical activities (at home, outside, in nature). Let's set an example to our youngest ones and work together to ensure that we are providing them with a healthy and active lifestyle. In the current situation, exercise and relaxation are the most important factors in remaining resilient, positive, and courageous, ready for all the challenges that await us in the coming weeks.

Needless to say, not every working parent can afford to commit at least an hour a day to family recreation.

${ }^{18} \mathrm{http}: / /$ www.pisrs.si/Pis.web/pregledPredpisa?id=USTA1 (accessed 15 December 2020).

19 Through the $5^{\text {th }}$ grade, primary schools in Slovenia offer extended school stay, a form of daily child care in which they also provide a range of extracurricular activities free of charge as well as some for a fee, with origins dating back to the 1950s. The majority of extracurricular activities too came to a halt during the lockdown, with some being moved to Zoom or Skype (e.g., music lessons, dance, judo, etc.). However, some activities, such as recreational football or basketball simply cannot be moved to Zoom. Moreover, with the reopening of schools in 2021, no extracurricular activities will take place in the schools, while some commercial activities outside the school have resumed. It is not surprising that, following the pandemic, the Ministry of Education is withdrawing financial support from schools for organizing free extra-curricular activities, for example swimming lessons in the first and third grades (https://www.rtvslo.si/slovenija/obslabsanju-gibalnih-sposobnosti-otrok-ministrstvo-sole-izlocilo-iz-razpisa-za-sportne-dejavnosti/573796, accessed 22 March 2021). 
The shifting discourse of personal responsibility during the pandemic is most clearly demonstrated in how the Minister of Education, as a government official, viewed children and young people whom she is supposed to work for. It seems that when the Minister stated during her interpellation that "they" knew all along who they were working for, she once again knew something we did not - namely who she was working for - and it clearly was not children and young people. In early February 2021, some high school students called for a boycott of distance education and the reopening of the schools. They also initiated a meeting with the Minister of Education. After jointly setting a date for an online meeting, the Ministry cancelled and postponed it for a week, setting it for the very day the student protest was announced. ${ }^{20}$ In the end, the Minister never met the students at all. Some of them took to the streets on February 9 which, in early March, resulted in five students getting fined EUR 400, and four underage students receiving summonses to defend themselves in the district court for allegedly violating the Communicable Diseases Act and posing a significant public health threat in Slovenia. While the majority of the public media saw this as a repressive act by the state apparatus and sided with the students, ${ }^{21}$ the Slovenian Minister of Education stated that "students must take responsibility for their actions, which is the first step into the world of adulthood". ${ }^{22}$ Speaking of personal responsibility, when the Minister came under fire in September 2020 for not wearing a face mask at a gala dinner, even though by then wearing one was required by government decree, the Minister simply tweeted an apology. ${ }^{23}$

As stated above, the pandemic demonstrates a growing trend of the state reducing its responsibilities and transferring it to individuals while opening the door to corporate interests. For example, state institutions in Slovenia, such as the Ministry of Education, have been promoting the use of Microsoft services (MS Teams) for distance learning with no discussion about the global corporate monopolisation of the supervision of the educational process, protection of privacy, and about what befalls the data which is being saved to the cloud. Already during the spring lockdown, the Ministry had signed a framework agreement with Microsoft and provided all primary and secondary schools licensed access to Microsoft tools including the videoconferencing system Teams (Logaj 2020: 94). In the

20 https://sloveniatimes.com/some-high-school-students-boycott-remote-learning-to-call-for-reopening/; https://www.delo.si/novice/slovenija/dijaki-v-torek-bojkot-pouka-na-daljavo/ (accessed 16 March 2021).

${ }^{21}$ Except for the right-wing news media outlet Nova24, founded by members and supporters of the Slovenian Democratic Party, which claimed that students were exploited for political purposes and that the protest was actually not a demand for students' return to school but rather a political demand for the resignation of the government led by the Slovenian Democratic Party (https://nova24tv.si/kolumna/politikantskoresevanje-vojakov-dijakov/, accessed 17 March 2021).

22 https://www.rtvslo.si/slovenija/sviz-in-ucitelji-ii-gimnazije-maribor-pozivajo-k-ustavitvi-postopkov-zoper-dijake/571879 (accessed 16 March 2021).

23 “I sincerely apologize and am sorry for not wearing a face mask at yesterday's event. According to the organizers, the event was organized in accordance with the recommendations and instructions of the National Institute of Public Health. For protective reasons, I will be preventively tested for COVID-19" (https:// www.rtvslo.si/slovenija/v-opoziciji-menijo-da-bi-morala-ministrica-kusteceva-zaradi-neuporabe-maskeodstopiti/536807, accessed 16 March 2021). 
spring, there were 421 schools actively using MS Teams, i.e. 58,000 active users at primary and secondary schools (Taštanoska 2020). With the second lockdown in autumn 2020, Microsoft tools were further integrated into the ARNES website and even more schools and teachers opted for Zoom and MS Teams videoconferences. Although the use of Office 365 for the purpose of distance learning implies that the user (i.e. the child) agrees to certain personal data being disclosed to the Office's services, the question has remained unanswered as to which data are stored, for what purpose, where they are stored, and who has access to them. This is despite the fact that since 2014, it was Microsoft that "first and most decisively turned toward surveillance capitalism as the means to restore its leadership in the tech sector" (Zuboff 2019: 161) and that the corporation has increasingly "assigned to establishing and securing supply routes to behavioural surplus" with a system that "gives itself a right to pass loads of your data to Microsoft's servers" (Zuboff 2019: 163-164).

The very description of Microsoft services is telling in itself: "Your productivity cloud across work and life." [In Slovenian, there is a further distinction, which translates to "across work and personal life".] We can therefore observe a change in the concept of productivity and the relationship between work and leisure, work and personal life, with the divide between them notably disappearing, which becomes particularly clear when we observe how the measures accompanying the pandemic during lockdown influence the reorganization of work, school, family responsibilities, and leisure. Furthermore, if we define "a productive worker" as referring to the production of surplus value (Harvey 2017: 99), for Microsoft productivity represents supply routes to behavioural surplus with the maximum flow of personal information to the corporation's servers (Zuboff 2019: 163-164).

\section{SELLING ONESELF AND ALGORITHMIC SURVEILLANCE}

The digital revolution introduced us to new forms of work, which, though not work in the traditional sense, represent a new system of capital accumulation. With algorithms continuously sourcing behavioural data, users of digital technology including children are not consumers or customers, but, as Shoshana Zuboff (2019) puts it, raw materials. The entirety of human life, from feelings and actions to personal preferences generates behavioural data, which Internet giants such as Google, Facebook, Apple, and Microsoft sell to their customers, generating profits precisely because their access to this data is free of charge; at the same time, people's lives are under increasing surveillance, which Shoshana Zuboff calls surveillance capitalism - people are no longer selling their work force, but literally themselves as a whole. It is no surprise that during the pandemic the revenues of the internet giants skyrocketed, as the market has previously already richly rewarded surveillance revenues (Zuboff 2019: 164).

On the one hand, we therefore have data sourcing as a new form of accumulating capital, while on the other, the use of algorithmic management, particularly by the socalled gig economy with representatives such as Uber, TaskRabbit, AmazonMTurk, Wolt 
and Deliveroo, ${ }^{24}$ where algorithms without any human supervision determine which employees will be assigned individual tasks based on their "performance", supervise and reward employees, and even determine which ones will be fired (Duggan et. al. 2020). And so, the tyranny of clocking in is being replaced by the tyranny of algorithms.

According to Foucault, in the $18^{\text {th }}$ century, school was established as "a machine for supervising, hierarchizing, rewarding" (Foucault 1995: 147) similar in these respects to supervision at workshops insofar as it tends "to observe the worker's presence and application, and the quality of his work; to compare workers with one another, to classify them according to skill and speed" (ibid.: 145). Already today, or at least in the near future, the surveillance, evaluation, punishment, discipline, and optimisation of individuals/students can be achieved by merely using algorithms. Yet algorithms as they function right now do not work in the interest of people but first and foremost in the service of corporate and commercial interests.

\section{CONCLUSION}

The pandemic demonstrates how biopolitics functions through security mechanisms. Faced with a threat, the government wants to ensure the safety of the population, but actually preserves the profit-increase-based economic system, which is currently shifting to the digital realm; to achieve this, it promotes an expansive network of surveillance technologies and practices. As Majia Holmer Nadesan (2010: 153, 159) observes, children are at the centre of the security discourse and healthcare of the whole of society as they are always at the centre of the process of the normalisation of society. This is a process through which newly formed norms of health, behaviour, manners, emoting, and social tensions gain general acceptance. At the same time, the neoliberal discourse perceives children as human capital. To states, children represent "an opportunity to shape and to secure a future for the populations they govern" (Lee 2013: 1; see also Apple 2013). The state invests in their education and health with the intention of shaping future generations according to its needs and ensuring that they contribute to the state's finances when they grow up.

Yet, as I have emphasized, such a notion of human capital is linked to "a narrow understanding of effectiveness in learning and what it is to be an effective young person" and

${ }^{24}$ With the COVID-19 pandemic there is a growing trend in food delivery platforms, for example Wolt. In 2016, Uber's attempt to start operating in Slovenia failed. It failed because the existing legislation did not support Uber's business model and the governments have so far refused to amend it. However, as part of the seventh package of rapid financial assistance to the population to prevent and mitigate the consequences of the pandemic, in December 2020, the Government of the Republic of Slovenia adopted a proposal to amend the Road Transport Act to finally provide a legal basis for platforms such as Uber - yet another example of opening the door to corporate interests in the midst of the pandemic alongside other examples from the fields of environmental protection, social security, urban planning etc. 
represents "a general concern to foster cognitive powers, whatever form they take, in the name of future flexibility and adaptiveness in the workforce" (Lee 2013: 92; see also Apple 2013; Griffiths et al. 2013; Hart and Boyden 2019; Giroux 2021). Furthermore, the concept of mental capital raises concerns "about the buying and selling of human capabilities and felt identities" (Lee 2013: 84), which is particularly pressing with the rise of surveillance capitalism.

New forms of work (for example, data harvesting as a new form of capital accumulation and social media influencing) have been emerging alongside the neoliberal entrepreneurial work ethic and the Digital Revolution for some time, while distance learning during the pandemic made them even more prominent. Here we can observe how unprecedented forms of "work", which include both the aspect of socialisation and discipline, are taking place. Distance learning, along the lines of the neoliberal entrepreneurial work ethic and the digitalisation of the school system is a suitable instrument for introducing new forms of "work", in which students are disciplined into mere users of technology without critical knowledge of it, while at the same time providing suitable raw material for the collection of behavioural data. In the chaos of the pandemic parents, teachers, and students usually do not find the collection and processing of their behavioural data problematic, because they do not see or feel any immediate negative consequences, and therefore willingly surrender their privacy and succumb to increased surveillance. In this way, children are no longer just an "economic stock for the future" (Millei 2020: 932), but already for the present.

Just as it took several generations for the population to accept a social organization based on waged-labour as self-evident, I suggest we are currently at the very start of the process that is generating specific forms of individuality and sociality in accordance with the needs of the transforming economic system, which is moving to the digital realm, where it is no longer propelled by a human workforce, but rather by the most intimate aspects of the human experience and personal data harvesting. At the same time, algorithmic management also gives rise to newly established forms of surveillance of individuals, measuring their usefulness and efficiency and disciplining them.

It is not surprising that the pandemic represents a push toward a new normal that has actually been on the horizon for some time. Central to understanding the neoliberal ideology is the inherent conviction that inequality is a natural state of society and that it is essential for competitiveness and the efficient functioning of the market (Holmer Nadesan 2010: 88). In this context, the discourse of social justice and equality is replaced by the discourse of personal responsibility. Because the system needs inequality in order to function, it not only deepens existing inequalities but also opens up the possibility for new ones. If state structures understand distance learning as competition in which they celebrate the winners, they will undoubtedly create losers. But even though state structures imbued with neoliberal ideology actually create losers while claiming they strive for equal opportunities for all, in yet another perverse turn they simultaneously place the responsibility for failure on them. 
However, it appears that generally the population in Slovenia is not favourably inclined to going fully online. The increased amount of time children spent online during the first wave of the pandemic was frequently listed among its negative aspects. Socialising and physical contact were the two most frequently emphasised commodities that could not be replaced with virtual approximations. Yet, school closures in the second wave of the pandemic pushed children online even more. Before the pandemic, children used digital platforms for leisure and fun, to escape social norms and adult supervision (see Turk Niskač 2020b). With distance learning during the pandemic, the digital domain has become compulsory, an obligation, and an overwhelming one, as both leisure and socialization activities have been increasingly confined to the same digital domain.

Distance learning influenced not only school and leisure activities of children and youth, but also all the in-between places and spaces, which, invisible to the adult gaze (although not necessarily invisible to algorithmic surveillance), significantly constitute their sociality (see Turk Niskač 2020b). Henry A. Giroux (2021) calls for critical pedagogy to counter social atomization, dehumanization and depoliticization of neoliberal discourse, and claims that the pandemic revealed the interconnectedness of lives. Yet, during the pandemic, neoliberal narratives are also being countered from below. Students boycotting distance learning were not demanding only that schools reopen, but were in fact reclaiming their sociality and interconnectedness. In a poem entitled Osamljena sreča (Lonely Happiness), published in the secondary school student magazine Novi dijak (New Student), ${ }^{25}$ Ela Potočnik wrote:

Zdaj vsak osamljen se sprašuje, kakšno življenje mu bit narekuje, ko $v$ mestih potihne govorjenje ljudi kdo si takrat, ko ostalih več ni? ${ }^{26}$

\section{REFERENCES AND SOURCES}

Apple, Michael W. 1993. "The Politics of Official Knowledge. Does a National Curriculum Make Sense?" Teachers College Record 95/2: 222-241.

Apple, Michael W. 2013. Can Education Change Society? New York, London: Routledge. https://doi. org/10.4324/9780203083550

Apple, Michael W. 2019. Ideology and Curriculum [4 $4^{\text {th }}$ edition]. New York, London: Routledge.

Becker, Gary S. 1993. Human Capital. A Theoretical and Empirical Analysis, with Special Reference to Education. Chicago, London: The University of Chicago Press. https://doi.org/10.7208/chicago/9780226041223.001.0001

25 https://novidijak.files.wordpress.com/2020/12/spoznanja-med-stirimi-stenami-4.pdf (accessed 17 March 2021).

${ }^{26}$ Now each of us lonely wonders / what sort of life Being dictates to us, / when people's speech is silenced in cities - / who are you when the others are gone? 
Berardi, Bifo Franco. 2009 The Soul at Work. From Alienation to Autonomy. Los Angeles: Semiotext(e).

Biti, Ozren. 2020. "Narratives about Work in Croatian Celebrity Culture”. Traditiones 49/3: 163-184. https://doi.org/10.3986/Traditio2020490308

Bond, Emma. 2013. "Mobile Phones, Risk and Responsibility. Understanding Children's Perceptions". CyberPsychology. Journal of Psychosocial Research on Cyberspace 7/1. Available at: http://www. cyberpsychology.eu/view.php?cisloclanku=2013011602 (accessed 22 January 2021). https://doi. org/10.5817/CP2013-1-3

Bond, Emma. 2014. Childhood, Mobile Technologies and Everyday Experiences. Changing Technologies=Changing Childhoods? London: Palgrave Macmillan. https://doi.org/10.1057/9781137292537

Bourdieu, Pierre. 1997. Outline of a Theory of Practice. Cambridge: Cambridge University Press.

Brie, Michael. 2017. "For an Alliance of Liberal Socialists and Libertarian Commonists. Nancy Fraser and Kar Polanyi. A Possible Dialogue". In Karl Polanyi in Dialogue. A Socialist Thinker of our Times. Michael Brie, ed. London: Black Rose Books, 7-64.

Brown, Gavin T. L. 2020. "Schooling Beyond COVID-19. An Unevenly Distributed Future". Frontiers in Education 5: 82. https://doi.org/10.3389/feduc.2020.00082

Bröckling, Ulrich. 2016. The Entrepreneurial Self. Fabricating a New Type of Subject. London: Sage. https://doi.org/10.4135/9781473921283

Danby, Susan J., Marilyn Fleer, Christina Davidson and Maria Hatzigianni, eds. 2018. Digital Childhoods. Technology and Children's Everyday Lives. (International Perspectives on Early Childhood Education and Development 22). Singapore: Springer. https://doi.org/10.1007/978-981-10-6484-5

DiPietro, Giorgio, Federico Biagi, Patricia Costa, Zbigniew Karpinski and Jacopo Mazza. 2020. The Likely Impact of COVID-19 on Education. Reflections based on the Existing Literature and Recent International Datasets. Luxembourg: Publications Office of the European Union. Available at: https:// op.europa.eu/en/publication-detail/-/publication/b48d50f6-b753-11ea-bb7a-01aa75ed71a1/ language-en (accessed 16 March 2021).

Duggan, James, Ultan Sherman, Ronan Carbery and Anthony McDonnell. 2020. "Algorithmic Management and App-work in the Gig Economy. A Research Agenda for Employment Relations and HRM". Human Resource Management Journal 30/1: 114-132. https://doi.org/10.1111/1748-8583.12258

Engzell, Per, Arun Frey and Mark Verhagen. 2021. "Learning Inequality During the Covid-19 Pandemic". Working Paper. Available at: https://osfio/preprints/socarxiv/ve4z7 (accessed 16 March 2021).

Federici, Silvia. 2012. Revolution at Point Zero. Housework, Reproduction, and Feminist Struggle. Oakland: PM Press.

Foucault, Michel. 1995. Discipline E Punish. The Birth of the Prison. New York: Vintage Books.

Foucault, Michel. 2008. The Birth of Biopolitics. Lectures at the Collège de France 1978-1979. New York: Palgrave Macmillan.

Fraser, Nancy. 2017. "A Triple Movement? Parsing the Politics of Crisis after Polanyi". In Karl Polanyi in Dialogue. A Socialist Thinker of our Times. Michael Brie, ed. London: Black Rose Books, 65-78. https://doi.org/10.1007/978-3-319-45590-7_3

Freire, Paulo. 2013. Education for Critical Consciousness. London: Bloomsbury Academic.

Giroux, Henry A. 2020. On Critical Pedagogy. London: Bloomsbury Academic. https://doi.org/ $10.5040 / 9781350145016$

Giroux, Henry A. 2021. Race, Politics and Pandemic Pedagogy. Education in a Time of Crisis. London: Bloomsbury Academic. https://doi.org/10.5040/9781350184466

Gorz, André. 1999. Reclaiming Work. Beyond the Wage-Based Society. Cambridge: Polity.

Harvey, David. 2017. Marx, Capital and the Madness of Economic Reason. London: Profile Books. 
Griffiths, Tom, Zsuzsa Millei and Robert Imre. 2013. Mass Education, Global Capital, and the World. The Theoretical Lenses of István Mészáros and Immanuel Wallerstein. New York: Palgrave Macmillan.

Hart, Jason and Jo Boyden. 2019. "Childhood (Re)materialized. Bringing Political Economy into the Field". In Reimagining Childhood Studies. Spyros Spyrou, Rachel Rosen and Daniel Thomas Cook, eds. London: Bloomsbury, 75-89.

Holmer Nadesan, Majia. 2010. Governing Childhood into the 215t Century. Biopolitical Technologies of Childhood Management and Education. New York: Palgrave Macmillan.

Jæger, Mads Meier and Ea Hoppe Blaabæk. 2020. "Inequality in Learning Opportunities During Covid-19. Evidence from Library Takeout". Research in Social Stratification and Mobility 68:1-5. https://doi. org/10.1016/j.rssm.2020.100524

Kovačič, Tanja and Pat Dolan. 2017. "The Relevance of Civic Engagement for Child and Youth Welfare. Lessons Learnt from Socialist and Post-socialist Slovenia". In The Routledge Handbook of Global Child Welfare. Pat Dolan and Nick Frost, eds. New York: Routledge, 124-136. https://doi. org/10.4324/9781315672960-13

Lahikainen, Anja Riitta, Tiina Mälkiä and Katja Repo. 2017. "Family, Media, and the Digitalization of Childhood". In Media, Family Interaction and the Digitalisation of Childhood. Anja Riitta Lahikainen, Tiina Mälkiä and Katja Repo, eds. Cheltenham, Northampton: Edward Elgar, 185-194. https://doi. org/10.4337/9781785366673

Lee, Nick. 2013. Childhood and Biopolitics. Climate Change, Life Processes and Human Future. New York: Palgrave Macmillan.

Logaj, Vinko, ed. 2020. Vzgoja in izobraževanje v Republiki Sloveniji v razmerah, povezanih s covid-19. Modeli in priporočila. Ljubljana: Ministrstvo za izobraževanje, znanost in šport, Zavod Republike Slovenije za šolstvo. Available at: https://www.zrss.si/pdf/modeli_in_priporocila.pdf (accessed 9 December 2020).

Millei, Zsuzsa. 2020. "Child as Human Capital". In The SAGE Encyclopedia of Children and Childhood Studies, 1-4. Daniel Thomas Cook, ed. Thousand Oaks: SAGE, 929-932.

Narotzky, Susana and Nico Besnier. 2014. "Crisis, Value, and Hope. Rethinking the Economy". Current Anthropology 55 /S9: S4-S16. https://doi.org/10.1086/676327

Ortner, Sherry B. 2016. "Dark Anthropology and its Others. Theory Since the Eighties". Hau. Journal of Ethnographic Theory 6/1: 47-73. https://doi.org/10.14318/hau6.1.004

Pezelj, Andrej. 2016. Umetnost in disciplina. Zgodovina urjenja umetnikov, tkalcev in beračev v klasični dobi. Ljubljana: Založba/ ${ }^{\star} c f$.

Sahlberg, Pasi. 2021. "Does the Pandemic Help us Make Education More Equitable?”. Educational Research for Policy and Practice 20: 11-18. https://doi.org/10.1007/s10671-020-09284-4

Spyrou, Spyros, Rachel Rosen and Daniel Thomas Cook. 2019. "Introduction. Reimagining Childhood Studies. Connectivities... Relationalities... Linkages...". In Reimagining Childhood Studies. Spyros Spyrou, Rachel Rosen and Daniel Thomas Cook, eds. London: Bloomsbury, 1-20.

Taštanoska, Tanja. 2020. "Presentation at the Roundtable Izobraževanje na daljavo. Izkušnje za prihodnost?". Available at: https://www.pei.si/wp-content/uploads/2020/06/Tastanoska.pdf (accessed 28 January 2021).

Turk Niskač, Barbara. 2020a. "Vpliv epidemije na vsakdanjik otrok in družinsko življenje. Rezultati ankete aprila 2020". Glasnik SED 60/2: 110-112. Available at: https://www.sed-drustvo.si/domains/ sed-drustvo.si/modules/Domino/Files/glasnik-60-2-2020-manjsa-resolucija.pdf (accessed 14 December 2020).

Turk Niskač, Barbara. 2020b. "Drobtinice prostega časa. Prosti čas otrok med produkcijo in potrošništvom". Etnolog 30: 15-28. 
Turk Niskač, Barbara. 2021a. O igri in delu. Antropologija zgodnjega otroštva. Ljubljana: Založba ZRC (Ethnologica Dissertationes; 7). https://doi.org/10.3986/9789610505181

Turk Niskač, Barbara. 2021b. "From Educational Work to Companionship. Juxtaposing Adults' and Children's Perspectives on Work and Play in Early Childhood". Childhood. A Global Journal of Child Research 28/1: 42-55. https://doi.org/10.1177/0907568220947137

Vodopivec, Nina. 2012. "Samoodgovornost. Paradigma sodobne modernizacije. Izziv ali grožnja". In Pomisli na jutri. O zgodovini (samo)odgovornosti. Andrej Studen, ed. Ljubljana: Inštitut za novejšo zgodovino, 232-245.

Williamson, Ben, Rebecca Eynon and John Potter. 2020. "Pandemic Politics, Pedagogies and Practices. Digital Technologies and Distance Education During the Coronavirus Emergency". Learning, Media and Technology 45/2: 107-114. https://doi.org/10.1080/17439884.2020.1761641

Woods, Philip, ed. 2009. Alternative Education for the 21st Century. Philosophies, Approaches, Visions. New York: Palgrave Macmillan. https://doi.org/10.1057/9780230618367

Zuboff, Shoshana. 2019. The Age of Surveillance Capitalism. The Fight for a Human Future at the New Frontier of Power. New York: Public Affairs.

\section{ŠKOLOVANJE NA DALJINU I NOVI OBLICI DISCIPLINE TIJEKOM PANDEMIJE}

U 19. stoljeću obavezno je školovanje uvedeno kao način discipliniranja u okviru novonastale radne etike oblikovane unutar moralnog diskursa produktivnosti te preokupacije države povećanjem profita. Tijekom pandemije bolesti COVID-19 obavezno se školovanje u Sloveniji preselilo u obiteljske domove, što je bilo moguće zbog poučavanja na daljinu i tehnoloških rješenja proizašlih iz digitalne revolucije. Budući da su u prelasku na učenje na daljinu škole bile uvelike prepuštene same sebi, uz tek neznatnu potporu državnih institucija, i budući da je većina odgovornosti pala na roditelje, pogotovo one s mlađom djecom, ministrica obrazovanja javno je proglasila učenike koronadobitnicima znanja, dobitnicima ovog i budućih vremena. Ipak, školovanje na daljinu ne može se promatrati izvan konteksta: naime, pandemija je promijenila organizaciju svakodnevnog života. Obitelji su se - svaka na svoj način - suočavale s time kako uskladiti školovanje na daljinu, obiteljske obaveze, rad i slobodno vrijeme. $U$ ovom se radu analiziraju promjene u svakodnevnom životu obitelji, zaštita privatnosti učenika i njihovih obitelji kao i funkcioniranje online tržišta, na temelju čega se školovanje na daljinu tumači kao novi oblik discipliniranja djece na razmeđu poduzetničke radne etike, digitalizacije i biopolitike.

Ključne riječi: poučavanje na daljinu, nadzorni kapitalizam, ljudski kapital, pandemija bolesti COVID-19 